\title{
Correlation and Path Analysis Studies in Brinjal (Solanum melongena L.)
}

\author{
Gajanana Kustagi $^{*}$, H.B. Lingaiah ${ }^{2}$, N. Jagadeesha ${ }^{3}$, B. Ravikumar ${ }^{4}$, \\ N. Ashok $^{5}$ and G.B. Srinivasulu ${ }^{6}$
}

${ }^{1}$ Division of Post-Harvest technology, ${ }^{3}$ Division of Agronomy, ${ }^{4}$ Division of Plant pathology, ${ }^{5}$ Division of Agricultural Economics,

${ }^{6}$ Division of floriculture and Land scape Architecture, College of Horticulture, Munirabad, University of Horticultural Sciences, Bagalkot, Karnataka, India

${ }^{2}$ Division of Horticulture, University of Horticultural Sciences, Bagalkot, Karnataka, India

*Corresponding author

Keywords

Correlation, Path analysis and Brinjal

Article Info

Accepted:

10 July 2019

Available Online:

10 August 2019

\section{A B S T R A C T}

A Field experiment was conducted at University of Agricultural Sciences, Bangalore with an objective to study the correlation and path analysis studies in Brinjal (Solanum melongena L.). The direct and indirect effects of yield components on fruit yield per plant in brinjal. In C-I fruit length $(0.8351)$ and plant height $(0.1554)$ recorded highest direct positive effects on fruit yield per plant. The major contribution of fruit length on fruit yield per plant was intensified further by positive indirect effect through plant height $(0.06560$ and fruit width $(0.0265)$. The direct effect of plant height on fruit yield per plant was mainly increased by the indirect effects through fruit length (0.3572) and fruit width (0.0246). In C-II fruit length (0.9324), number of fruit per cluster (0.3028) and number of fruit per plant (0.2544) recorded highest direct positive effects on fruit yield per plant. The major contribution of fruit length on fruit yield per plant was intensified further by positive indirect effects through plant height (0.0233) and per cent fruit set (0.0321). The direct effect of number of fruit per cluster on fruit yield per plant was mainly increased by the indirect effects through per cent fruit set (0.0321). The direct effect of number of fruit per plant on fruit yield was intensified further by positive indirect effects through number of fruit per cluster and fruit width. 


\section{Introduction}

Brinjal (Solanum melongena L.) is one of the important solanaceous vegetable crops grown almost throughout the country. Yield which is a dependent character is the resultant effect of a number of component characters, but direct selection for yield is often misleading and hence knowledge of interrelationship between pairs of these characters and yield is essential to bring a rational improvement in the desirable traits. Further, path coefficient analysis is helpful in partitioning the observed correlation coefficients into direct and indirect effects and their effective use in selection programme. Keeping this in view the present study was undertaken to work out the association of important traits and to study the path coefficient analysis in brinjal.

\section{Materials and Methods}

A Field experiment was conducted at University of Agricultural Sciences, Bangalore with an objective to study the Genetics of quantitative traits in Brinjal (Solanum melongena L.).The soil of the experimental site was red sandy loam in texture classified under the order Alfisols, Vijapura series, isohyperthermic family of oxihaplustaf. $\mathrm{pH}$ was slightly acidic (6.44) having low cation exchange capacity $(7.50 \mathrm{C}$ mol $\mathrm{kg}^{-1}$ ) with an electrical conductivity of $0.23 \mathrm{dSm}^{-1}$. The average annual rainfall was $927 \mathrm{~mm}$ distributed in 62 rainy days $(>2.5$ $\mathrm{mm})$. The present investigation was carried out with Six diverse parents were crossed in a half diallel fashion without reciprocals to obtain 15 hybrids. Among the hybrid combinations developed from diallel cross, two hybrids i.e. Arka Keshav X Arka Sheel and Arka Sheel XAnnamalai were chosen for generation mean analysis. $\mathrm{F}_{1}$ 's were raised and selfed to get $F_{2}$ population. Further, $F_{1}$ 's were crossed to respective parents to get $\mathrm{BC}_{1} \mathrm{P}_{1}$ and $\mathrm{BC}_{1} \mathrm{P}_{2}$ seeds. The seeds of six generations were sown in trays at vegetable seed production block, Division of Horticulture, University of Agricultural Sciences. G. K. V. $\mathrm{K}$. Bangalore. Four week old healthy seedlings were transplanted at a spacing of $60 \times 60 \mathrm{~cm}$ in randomized complete block design with three replications. All the recommended package of practices was followed during the crop period. The correlation coefficient analysis among all possible character combination was worked out following the procedure described by Al-Jibouri et al., (1958). While, direct and indirect effect of component characters on fruit yield were estimated following Dewey and Lu (1959).

\section{Results and Discussion}

The estimates of phenotypic correlation coefficients among nine characters are presented in Table 1 and 2. In C-II fruit yield per plant was positive and significant correlation with fruit length (0.4223), fruit width (0.5311) and number of fruits per plant (0.9191). Number of fruits per plant with fruit width (0.4223): per cent fruit set with number of fruit per cluster (0.7352): Number of fruit per cluster with plant height (0.6763), number of branches (0.7158) and number of flower per cluster (0.8883): Number of flower per cluster with plant height (0.7592) and number of branches (0.8181). In C-I fruit yield per plant was positive and significant correlation with number of fruits per plant(0.9648): per cent fruit set with plant height (0.4513), number of branches (0.4598), number of flower per cluster (0.5551) and number of fruit per cluster (0.8368): Number of fruit per cluster with plant height (0.7100), number of branches (0.7534) and number of flower per cluster (0.9146): Number of flower per cluster with plant height (0.7539) and number of branches(0.8067): number of branches per plant with plant height (0.8811). Similar findings were reported by Chadha and Sidhu (1983). 
Table.1 Estimates of phenotypic correlation coefficients for nine quantitative traits in $\mathrm{F}_{2}$ population of cross I

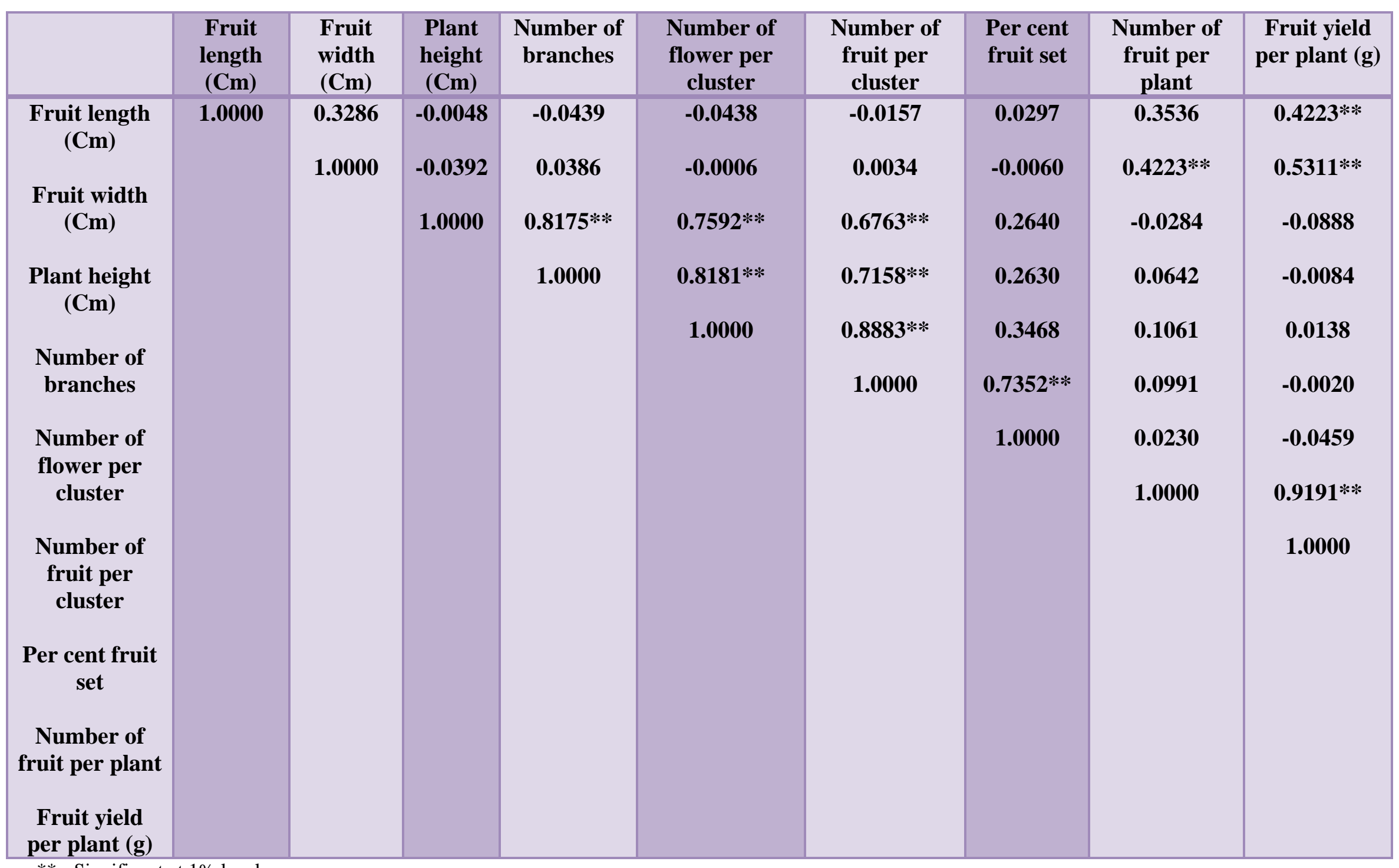

** - Significant at $1 \%$ level 
Table.2 Estimates of phenotypic correlation coefficients for nine quantitative traits in $\mathrm{F}_{2}$ population of cross II

\begin{tabular}{|c|c|c|c|c|c|c|c|c|c|}
\hline & $\begin{array}{l}\text { Fruit length } \\
(\mathrm{Cm})\end{array}$ & $\begin{array}{l}\text { Fruit width } \\
(\mathbf{C m})\end{array}$ & $\begin{array}{l}\text { Plant height } \\
(\mathbf{C m})\end{array}$ & $\begin{array}{l}\text { Number of } \\
\text { branches }\end{array}$ & $\begin{array}{l}\text { Number of flower } \\
\text { per cluster }\end{array}$ & $\begin{array}{l}\text { Number of fruit } \\
\text { per cluster }\end{array}$ & $\begin{array}{l}\text { Per cent fruit } \\
\text { set }\end{array}$ & $\begin{array}{l}\text { Number of } \\
\text { fruit per plant }\end{array}$ & $\begin{array}{l}\text { Fruit yield per } \\
\text { plant (g) }\end{array}$ \\
\hline Fruit length $(\mathbf{C m})$ & 1.0000 & -0.0549 & -0.0114 & -0.0025 & 0.0497 & 0.0250 & -0.0034 & -0.1129 & -0.1272 \\
\hline Fruit width $(\mathbf{C m})$ & & 1.0000 & -0.1899 & -0.1414 & -0.1103 & -0.1091 & -0.0720 & 0.2901 & 0.3645 \\
\hline Plant height $(\mathbf{C m})$ & & & 1.0000 & $0.8811 * *$ & $0.7539 * *$ & $0.7100 * *$ & $0.4513 * *$ & -0.0766 & -0.1395 \\
\hline Number of branches & & & & 1.0000 & $0.8067 * *$ & $0.7534 * *$ & $0.4598 * *$ & -0.1009 & -0.1496 \\
\hline Number of flower per cluster & & & & & 1.0000 & $0.9146 * *$ & $0.5551 * *$ & -0.1082 & -0.1279 \\
\hline Number of fruit per cluster & & & & & & 1.0000 & $0.8368 * *$ & -0.0757 & -0.0831 \\
\hline Per cent fruit set & & & & & & & 1.0000 & -0.0018 & 0.0166 \\
\hline Number of fruit per plant & & & & & & & & 1.0000 & $0.9648 * *$ \\
\hline Fruit yield per plant (g) & & & & & & & & & 1.0000 \\
\hline
\end{tabular}

$$
\text { ** - Significant at } 1 \% \text { level }
$$

Table.3 Estimates of direct and indirect effects of yield components on fruit yield in $\mathrm{F}_{2}$ population of cross I

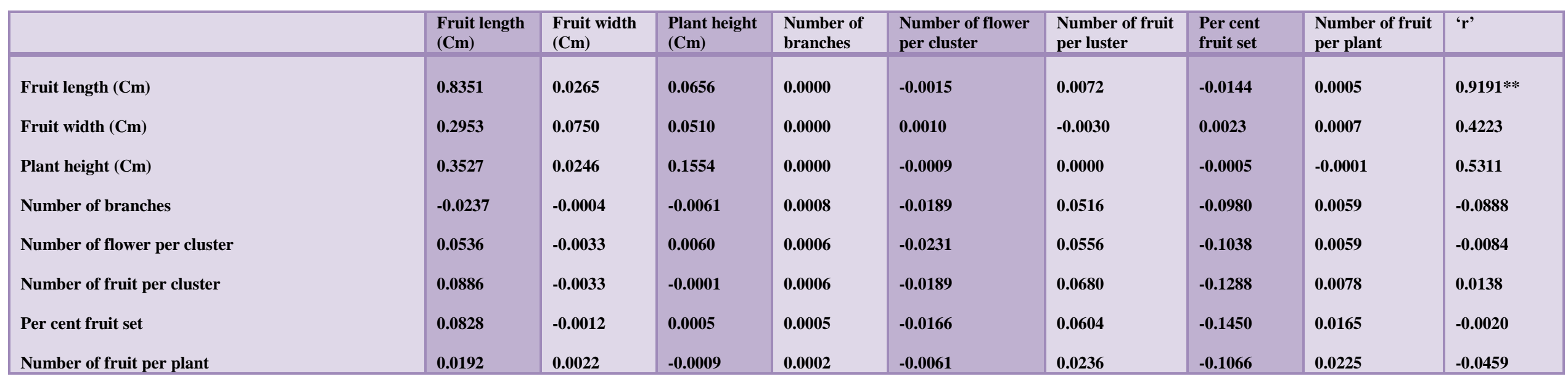

Main diagonal (in bold) are direct effects

Residual $=0.1180$ 
Table.4 Estimates of direct and indirect effects of yield components on fruit yield in $\mathrm{F}_{2}$ population of cross II

\begin{tabular}{|c|c|c|c|c|c|c|c|c|c|}
\hline & $\begin{array}{l}\text { Fruit } \\
\text { length } \\
(\mathrm{Cm})\end{array}$ & $\begin{array}{l}\text { Fruit } \\
\text { width } \\
\text { (Cm) }\end{array}$ & $\begin{array}{l}\text { Plant } \\
\text { height } \\
(\mathrm{Cm})\end{array}$ & $\begin{array}{l}\text { Number } \\
\text { of } \\
\text { branches }\end{array}$ & $\begin{array}{l}\text { Number of } \\
\text { flower per } \\
\text { cluster }\end{array}$ & $\begin{array}{l}\text { Number of } \\
\text { fruit per } \\
\text { cluster }\end{array}$ & $\begin{array}{l}\text { Per cent } \\
\text { fruit set }\end{array}$ & $\begin{array}{l}\text { Number } \\
\text { of fruit } \\
\text { per plant }\end{array}$ & 'r' \\
\hline Fruit length (Cm) & 0.9324 & 0.0025 & 0.0233 & 0.0066 & 0.0010 & -0.0328 & 0.0321 & -0.0004 & $0.9648 * *$ \\
\hline Fruit width $(\mathrm{Cm})$ & -0.1053 & -0.0222 & -0.0044 & 0.0010 & 0.0000 & 0.0150 & -0.0106 & -0.0009 & -0.1272 \\
\hline Plant height (Cm) & 0.2705 & 0.0012 & 0.0804 & 0.0164 & 0.0014 & -0.0334 & 0.0463 & -0.0183 & 0.3645 \\
\hline Number of branches & -0.0715 & 0.0003 & -0.0153 & -0.0863 & -0.0085 & 0.2283 & -0.3014 & 0.1148 & -0.1395 \\
\hline Number of flower per cluster & -0.0940 & 0.0001 & -0.0114 & -0.0761 & -0.0096 & 0.2443 & -0.3198 & 0.1170 & -0.1496 \\
\hline Number of fruit per cluster & -0.1009 & -0.0011 & -0.0089 & -0.0651 & -0.0078 & 0.3028 & -0.3883 & 0.1412 & -0.1279 \\
\hline Per cent fruit set & -0.0706 & -0.0006 & -0.0088 & -0.0613 & -0.0073 & 0.2770 & -0.4245 & 0.2129 & -0.0831 \\
\hline Number of fruit per plant & -0.0016 & 0.0001 & -0.0058 & -0.0390 & -0.0044 & 0.1681 & -0.3552 & 0.2544 & 0.0166 \\
\hline
\end{tabular}


The direct and indirect effects of yield components on fruit yield per plant are presented in Table 3 and 4. In C-I fruit length $(0.8351)$ and plant height $(0.1554)$ recorded highest direct positive effects on fruit yield per plant. The major contribution of fruit length on fruit yield per plant was intensified further by positive indirect effect through plant height $(0.06560$ and fruit width (0.0265). The direct effect of plant height on fruit yield per plant was mainly increased by the indirect effects through fruit length (0.3572) and fruit width (0.0246). In C-II fruit length (0.9324), number of fruit per cluster (0.3028) and number of fruit per plant (0.2544) recorded highest direct positive effects on fruit yield per plant. The major contribution of fruit length on fruit yield per plant was intensified further by positive indirect effects through plant height (0.0233) and per cent fruit set (0.0321). The direct effect of number of fruit per cluster on fruit yield per plant was mainly increased by the indirect effects through per cent fruit set (0.0321). The direct effect of number of fruit per plant on fruit yield was intensified further by positive indirect effects through number of fruit per cluster and fruit width. These findings are in agreement with the findings of Rathod (1997), Patil (1998) and Bhutani and Kalloo (1991).

\section{References}

Al-Jibouri, H.A., Miller, P.A. and Robinson, H.V., 1958, Genotypic and environmental variances and covariances in an upland cotton cross of inter specific origin. Agronomy J, 50: 633-636.

Bhutani, R. D. and Kalloo, G, 1991, Inheritance studies of locule number in tomato. Haryana J. Hort. Sci. 20(1-2): 119-124.

Chadha, M. L. and Sidhu, S., 1982, Studies on hybrid vigour in brinjal (Solanum melongena L). Indian J. Hort., 39: 233238.

Dewey, D.R. and Lu, K.H., 1959, A correlation and Path coefficient analysis of components of crested wheat grass seed production. Agronomy J. 51: 515518.

Patil, R.V., 1998, Heterosis, combining ability and disease reaction studies in brinjal. Ph.D. Thesis, University of Agril Sci, Dharwad.

Rathod, S.J., 1997, Evaluation of tomato genotypes for productivity and processing traits during late rabi season. $M$ Sc (Agri) Thesis, University of Agricultural Sciences, Dharwad.

\section{How to cite this article:}

Gajanana Kustagi, H.B. Lingaiah, N. Jagadeesha, B. Ravikumar, N. Ashok and Srinivasulu, G.B. 2019. Correlation and Path Analysis Studies in Brinjal (Solanum melongena L.). Int.J.Curr.Microbiol.App.Sci. 8(08): 1100-1105. doi: https://doi.org/10.20546/ijcmas.2019.808.128 